\title{
The friendship of Matthew and Paul: A response to a recent trend IN THE INTERPRETATION OF MATTHEW'S GOSPEL
}

\author{
Author: \\ Joel Willitts ${ }^{1,2}$

\begin{abstract}
Affiliations:
Studies, North Park

University, USA

${ }^{2}$ Faculty of Theology, University of Pretoria,

South Africa
\end{abstract} \\ ${ }^{1}$ Biblical and Theological
}

\section{Correspondence to:}

Joel Willitts

e-mail:

jwillitts@northpark.edu

\section{Postal address:}

North Park University,

3225 W. Foster Ave,

Chicago, IL 60625, USA

\section{Keywords:}

Gospel of Matthew;

Matthew's Great

Commission; Tübingen

School; Paul's Gentile

mission; Jewish

Christianity

Dates:

Received: 05 Jan. 2009

Accepted: 19 Mar. 2009

Published: 24 July 2009

How to cite this article: Willitts, J., 2009, 'The friendship of Matthew and Paul: A response to the recent trend in the interpretation of Matthew's Gospel', HTS Teologiese Studies/

Theological Studies 65(1), Art. \#151, 8 pages. DOI: 10.4102/hts.v65i1.151

\section{This article is available} at:

http://www.hts.org.za

\section{Note:}

Dr Willitts participates as a Research Associate in the research project 'Biblical Theology and Hermeneutics', directed by Prof. Andries G. van Aarde, Honorary Professor of the Faculty of Theology at the University of Pretoria, South Africa.

(C) 2009. The Authors. Licensee: OpenJournals Publishing. This work is licensed under the Creative Commons Attribution License.

\section{ABSTRACT}

David Sim has argued that Matthew's so-called Great Commission (Mt 28:16-20) represents a direct anti-Pauline polemic. While this thesis may be theoretically possible and perhaps fits within the perspective of an earlier era in New Testament research, namely that of the Tübingen School, the evidence in both Matthew and the Pauline corpus does not support such a reading of early Christianity. In this paper, I argue that an antithetical relationship between Matthew's Great Commission and Paul's Gentile mission as reflected in his epistles is possible only (1) with a certain reading of Matthew and (2) with a caricature of Paul. In light of the most recent research on both Matthew's Great Commission and the historical Paul, these two traditions can be seen as harmonious and not antithetical in spite of the recent arguments to the contrary. My argument provides a further corrective to the view of early Christianity, which posits a deep schism between so-called Jewish Christianity and Paul's ostensibly Law-free mission to the Gentiles.

\section{INTRODUCTION}

Over a decade ago, Luz wrote the following about Matthew and Paul: 'had they known one another, [they] would certainly not have struck up a strong friendship' (1995:148). While Luz clearly did not think that Matthew knew of Paul or that he was directly engaging Paul's theological perspective, he nevertheless believed that Matthew and Paul's theologies were incompatible. Luz's point of view is not, of course, unique but, for the majority of Matthean scholars, it is fair to say that it is Stanton's assessment that is the common one: 'Matthew's gospel as a whole is neither anti-Pauline, nor has it been strongly influenced by Paul's writings; it is simply un-Pauline' (1993:314; also see Mohrlang 1984). In the last decade, however, a formidable, albeit largely singular, voice (which does appear to be gaining some traction), ${ }^{1}$ has taken Luz's perspective to the extreme. Beginning in his doctoral dissertation (which was to be published later) and following on in a series of articles as well as in a lengthy monograph, Sim has attempted to show that Matthew and Paul, more than simply having a non-relationship as Luz imagined, were in fact adversaries, that is at least from Matthew's perspective (1995:4; 1996a:210-219; 1996b; 1998:165-213, also see 69, 19-27, 63-107, 236-256; 2002; 2009 [forthcoming]; Sim \& Repschinski 2008).

Sim, by his own admission, has attempted to 'resurrect the [failed] thesis' of Brandon (1957), who, over a half century ago, unconvincingly argued, as acknowledged by Sim, that Matthew was 'intensely antiPauline' (Sim 2008:380). ${ }^{2}$ The title of Sim's 2002 article, Matthew's anti-Paulinism: A neglected feature of Matthean studies, serves my point. One immediately notices Sim's unqualified assertion, which is not that Matthew's Gospel might contain themes that could be understood as anti-Pauline but rather that the First Gospel is anti-Pauline:

Matthew's Jewish Christian perspective, his support for a Law-observant Gentile mission and the presence of anti-Pauline texts in his Gospel ... pointed inevitably to the conclusion that Matthew was engaged in a bitter and sustained polemic against Paul himself.

(Sim 2002:777)

Here Sim has listed three primary reasons for his view:

- Matthew's Jewish-Christian perspective

- Matthew's support for a Law-observant Gentile mission

- The presence of anti-Pauline texts in Matthew's Gospel.

These points emerged out of his 1998 The Gospel of Matthew and Christian Judaism: The history and social

1.See Harrington (2008:24-26), who appears sympathetic to Sim's view, although he did offer somewhat of a backhanded compliment when he stated, 'While the evidence for Sim's hypothesis may not seem totally convincing to all, at the very least he has provided a stimulus for us to rethink our largely canon-influenced tendency to harmonize Paul and Matthew'.

Catchpole also advocated an approach to Matthew like Sim's when he figuratively suggested that 'the ghost of Paul' lurked on the stage on which Matthew's drama played out (2002:33). He posited that Matthew's 'all the nations' (Mt 28:20) 'necessarily involved him in taking a position on the Pauline version of Christianity' (2002:33). Furthermore, after establishing the universality of Matthew's understanding of mission, he argued on the basis of Matthean redaction that 'we are pressed toward the conclusion that Matthean Christianity is fundamentally at variance with Pauline Christianity' and that 'the real Christian threat [Mt 5:17-19; 7:15-23] that concerns the evangelist may well come from the direction of the Pauline tradition' (2002:44). Catchpole did, however, diverge from Sim in his understanding of Matthew's positive outlook on the Gentiles. While agreeing with Sim that Matthew's community would have required Gentiles to become Jews to be full members of the people of God, Catchpole argued that Matthew's universalism 'implied dutiful and determined mission whose goal was faithful recognition of the resurrected Lord by persons of any and every ethnic background' (2002:62). Sim, on the other hand, thought that Matthew was not only anti-Pauline but also anti-Gentile. According to Sim (at least in his earlier work: his most recent article dealing with the Great Commission has implied that Matthew was involved in a Gentile mission, which seems to evince a contradiction), althoug Matthew's community may hav reconised a Gentile mission, it neither actively conducted mission to nor was contradiction), although Mathew's community may have recognised a Gente mission, it neither actively conducted mission to nor was in regular contact with Gentles. 'The members of this Christian Jewish group avoided the Gentle world and were not conducting or even contemplating a mission to the Gentiles' (Sim 1998:28; 236-256; also see 1995). Catchpole's arguments are addressed indirectly by
my critique of Sim below. 2.Davies (1964:316-341) provided the most devastating and definitive critique of Brandon's views in print in his The setting of the sermon on the mount

(1) 
setting of the Matthean community, in which Sim provided a detailed case for Matthew's anti-Paulinism. ${ }^{3}$ Sim published two additional articles (another is soon to appear), in which he expanded discussions that he first set out in his 1998 monograph in an attempt to grow the list of Matthean texts that demonstrate an anti-Pauline perspective (2007; 2008; 2009 [forthcoming]). In his most recently published article, titled Matthew, Paul and the origin and nature of the Gentile mission: The Great Commission in Matthew 28:16-20 as an anti-Pauline tradition (2008), he sought to show that Matthew's so-called Great Commission (Mt 28:16-20) should be included among the anti-Pauline texts in Matthew. He wrote:

I have contended that Matthew's major emphasis on the Torah sets him at odds with the Law-free position of Paul, and that a number of Matthean texts (5:17-19; 7:13-27; 13:36-43; 16:17-19) were included and/or redacted in order to counter either the person or the theology of the apostle. The Great Commission that concludes the Gospel can be added to the growing list of anti-Pauline Matthean texts.

(Sim 2008:380; also see Sim 2007:343)

The purpose of my paper is to assess Sim's interpretation of Matthew's Great Commission (28:16-20) as an overtly antiPauline polemic. While my paper is narrowly focused, I hope that it will nevertheless have wider implications for the hypothesis that Matthew's Gospel is anti-Pauline.

\section{The Historical Paul}

The point where I would like to begin my assessment of Sim's proposal is his presentation of the Apostle Paul. I have two reasons for this: firstly, Sim's study of the Great Commission begins with a sketch of Paul's view of the Gentile mission; and, secondly and more importantly, it is fair to say that Sim's interpretation of an anti-Pauline Matthew rises or falls on the question of who the historical Paul was.

Sim has described Paul's position on the origin and nature of the Gentile mission with five points based on his interpretation of the first two chapters of Galatians (2008:380-383). Against this interpretative grid, Sim has read Matthew's Great Commission to be 'explicitly or implicitly' refuting Paul (2008:388-389). Given the grid's foundational nature for Sim's argument, I will briefly analyse the most significant of these points.

Firstly, Sim has asserted that, according to Paul, there were 'two separate and independent' missions in the early Christian movement (2008:382). This characterisation of Paul's words is arguable. While there can be no debate that Paul spoke of a mission to the circumcised and of one to the uncircumcised, Sim's interpretation of Paul's statement was more than what Paul said: Paul did not assert two separate and independent missions. Two missions, yes, but the antithetical characterisation of them does not follow. In fact, one can easily - perhaps more easily - characterise the two missions that Paul mentioned as being conjoined and complementary. The mention of Barnabas by Paul in Galatians 2:9 is not insignificant in this regard: 'they gave to Barnabas and me the right hand of fellowship. 'Furthermore, not only is it interesting that Barnabas' name was mentioned first in the possible implications for the relative status of the two figures; the recognition of Barnabas' role in the mission of the early church is equally interesting. According to the New Testament, Barnabas was a liminal figure, stretching across both the circumcised and the uncircumcised missions. His very presence in this context speaks against taking the missions as 'separate and independent' because figures like Barnabas and, dare we say, many more nameless figures, were regularly bridging the two missions. ${ }^{4}$

3.Sim attempted to establish the anti-Pauline perspective in Matthew by an appeal to Matthew's treatment of (1) the disciples, (2) James and the relatives of Jesus, (3) Peter and (4) anti-Pauline texts, where 'Matthew vigorously attacks Paul and his law-free gospel' (Sim 1998:199; also see 188-212).
Secondly, Sim has contended that Galatians 1 to 2 make the point that the two missions 'conveyed different gospels to their respective missionary targets' (2008:382). While I agree with Sim to an extent, namely that the preaching of the gospel to the Gentiles (alternatively to Israel) carried unique implications for Torah observance for the respective groups, I do not agree that these distinctions warrant Sim's conclusion of 'different gospels'. Paul insisted on the one gospel (Gl 1:6-8), the same gospel entrusted to both Peter and himself (Gl 2:7). There seem to be differing implications of the one gospel for Jews and Gentiles however, which therefore necessitated a two-pronged missional strategy (also see 1 Cor 7:17-21). This 'one gospel, but different implications' seems to be the point of the two accounts in Galatians 2. Paul and the Jerusalem 'pillars' agreed on the gospel and expressed the variegated implications based on ethnic distinction (Gl 2:1-10). Furthermore, when Peter acted in a way contrary to the one agreed-upon gospel and its implication for Gentiles, Paul stood against him (Gl 2:11-21). Of particular note is Paul's accusation against Peter: Paul accused Peter of hypocrisy, not apostasy or heresy. In so doing, Paul implied that the problem was Peter's situational adjustment of his behaviour and not that Peter taught another gospel.

Finally, Sim has stated that the 'two independent missions came under the authority of different people, namely Paul and Peter' (Sim 2008:382). He has drawn the following conclusion from this interpretation:

Paul had no responsibility for or authority over the Jewish mission headed by Peter. Conversely, and more importantly, Peter and the others in Jerusalem church were to have no involvement in the Gentile mission and certainly no authority over it.

(Sim 2008:382)

Both the conclusion and the interpretation upon which it is based are problematic and cannot be sustained by a plain reading of Galatians 2. Evident in the text is Paul's recognition of the authority of the Jerusalem church. This recognition can be seen in three ways: (1) Paul stated that he 'laid before them the gospel which he preached among the Gentiles' (Gl 2:2); (2) Paul remembered that he was given 'the right hand of fellowship' and a consequent recognition of the legitimacy of his mission to the Gentiles (Gl 2:9); and (3) Paul referred to a stipulation that was given to him by the Jerusalem church that he not only agreed to but was, in fact, already enacting (Gl 2:10). These implicit points resemble Luke's more explicit presentation in Acts, especially Acts 15 and 21. Galatians 1 and 2 present Paul as a pioneer undoubtedly and independently called to his apostleship but, taken as a whole, the chapters suggest that Paul was concerned about being in good standing with the church in Jerusalem in spite of arguments to the contrary. ${ }^{6}$ Furthermore, Sim's conclusion that Paul 'had no responsibility or authority over the Jewish mission' is perhaps true but irrelevant. Paul never claimed to have this authority nor did he seek it, although he did make clear that his Gentile mission was motivated by his desire to be an agent of the salvation of his own people ( $\mu$ ou inv бópкo) (Rm 11:13-14). In addition, Peter did not seem to hold the unique apostolic authority in early Christianity that Sim has attributed to him. It was James who clearly emerged as the leader of the Jerusalem church. ${ }^{7}$

4.See Bauckham's recent suggestion that Barnabas was likely a founder of the Jerusalem church (2006:84-85; also see 81-92), as may be the case with Ananias, Apollos, John Mark, Philip, Silas and Junia, who was 'in Christ' before Paul (Rm 16:7). Also see Hvalvik's discussion of Jewish believers connected with the Pauline mission (2006).

5.For a thorough discussion of this point, see Nanos (2002).

6.In addition to the evidence here, other indications can be observed from Paul's letters that, at the very least hint at Paul's recognition of the authority of the Jerusalem church. For example, Paul's rational for the offering for the of the Jerusalem church. For example, Paul's rationale for the offering for the Jerusalem church was suggestive (Rm 15:26-28). Therefore, the comment by Davies about the relationship between Paul and the Jerusalem church remain valid: While there were differences in the early church between Paul and 'the Judaizers', which cannot be ignored, the fundamental fact remains that according to Galatians and Acts the Jerusalem leaders accepted the Gentile mission of Paul with few conditions' (1964:325). 
What is more, it is simply false to allege that Peter and the Jerusalem church were to have 'no involvement in the Gentile mission'. This claim not only excessively overreaches what the text says but is also at odds with evidence within and outside of Paul's letters. Firstly, nowhere did Paul claim to be the only or even the central apostle to the Gentiles. He did, in fact, acknowledge that he was just one of perhaps many when he stated, 'Inasmuch as I am an apostle to the Gentiles' (Rm 11:1314; also see 2 Cor 3:4-6). ${ }^{8}$ Secondly, as already noted, there were liminal figures who crossed back and forth between ethnically distinct missions. Thirdly, Paul's statement in Romans 1:16 that '[the gospel] is the power of God for salvation ... to the Jew first and also to the Greek', along with the Jew/Gentile issue discussed in Romans 14 to 15, suggests that Luke's presentation of Paul's missionary strategy of preaching in synagogues in the cities that he visited was not far from the truth. ${ }^{9}$ It is even possible to suggest, as New Testament archaeologist McRay (2003) does, that Paul's choice of cities was the result of the presence of a Diaspora synagogue. ${ }^{10}$

It seems, then, that Sim's interpretation of Paul's view of the origin of the Gentile mission, based as it is on his interpretation of Galatians 1 to 2, contains significant enough weaknesses to call into question his assertion that the Great Commission refuted Paul. It would appear that the Paul whom Matthew supposedly refuted disappeared.

The point here is not to deny that some of Paul's contemporaries, both Jesus-believing and not, misunderstood him or that Paul had a number of enemies - this is beyond question from the evidence. However, the historical reconstruction of Paul essential to Sim's understanding of early Christian history, to the extent that it resembles a baurite perspective, continues to suffer severe criticism. ${ }^{11}$ What is more, some of the most recent trends in Pauline scholarship increasingly render such a picture untenable.

One such trend that is gaining broad international support is the 'Torah-observant Paul'. ${ }^{12}$ Within this line of interpretation, the Paul of history did not hold that 'the ritual requirements of Judaism, the observances which marked the Jews as a race apart from other peoples, were no longer appropriate in light of the coming of Christ' (Sim 1998:21-22; 2008:385; Sim \& Repschinski 2008:4); had not himself 'abandoned' Torah observance while conducting his mission (Sim 1998:22; 2008:386) ${ }^{13}$; did not behave in a chameleon-like manner, observing the law only

7.See Acts 21. Also see the discussions by Bauckham (1990; 1995; 2006).

8.See the recent discussion by Jewett (2007:678-679). In critiquing Brandon's views, Davies made this point eloquently long ago: 'Paul's activity took place within the context of a vast missionary expansion' (1964:320).

9.Also see Davies (1964:331).

10.See McRay (2003:141).

11.See the critique by Davies of Brandon (1964:324-325) and, most recently, by Bockmuehl (2006). In contrast, Marcus (2000) observed the re-emergence of Baur's thesis on postwar Pauline scholarship, which, to his mind provided part of the mistivation for recent projects on Paul and Mark. No doubt of great part of the motivation for recent projects on Paul and Mark. No doubt of great influence in this regard was the work by Martyn (1997a; 1997b). Also clearly influential, particularly for Sim, was Lüdemann's the Opposition to Paul in Jewish Christianity (1989). In a chapter titled 'The Matthean community and Pauline Christianity' in Sim's 1998 monograph, he approvingly cited Lüdemann more than 12 times (1998:165-213).

12.The excellent soon-to-be-published essay Rethinking the "Paul and Judaism" paradigm: Why not "Paul's Judaism"? by Mark Nanos (2009b [forthcoming]) at http://marknanos.com/Paul\%27sJudaism-5-28-08.pdf (2008, 15 September) would be a good place to begin looking at this 'New View' of Paul's. Also see Bockmuehl (2003), Campbell (2006), Ehrensperger (2007), Eisenbaum (2000-2001), Gager (2000), Nanos (1996), Rudolph (2006; 2009 [forthcoming]), Tomson (2001a), Wyschogrod (2004) and Zetterholm (2007).

13. Mohrlang's study of Matthew's and Paul's ethics carried the same bias: 'That Paul the Christian continues to observe the traditional practices of the Jewish law as a Pharisee is beyond belief... There is nothing in his writings to suggest that his ordinary daily life and conduct are governed by legal regulations halakic-style (1984.39-40). Perhaps contributing to such a vew was Mohrlang's insistence on maintaining the false distinction between 'moral' and 'ritual' requirements of the Law in Paul's thinking (1984:33-34). when missionally convenient (Sim 1998:22, 24); or did not deny 'the very fundamentals of Judaism' (Sim 1998:23). Rather, the historical Paul continued to identify himself as 'an adherent of the Jewish faith' and lived 'within the confines of Judaism'; and remained a Jew after his Damascus-road experience as a matter of 'religious commitment' (Sim 1998:23-24).

Had this alternative Paul of history and Sim's hypothetical Matthew been contemporaries, this Paul would surely have been in conflict with him over his insistence that Gentiles needed to be circumcised to be counted among participants in the Messianic restoration with Jesus-believing Israelites. Yet this Paul would not have disagreed with this Matthew on the abiding nature of the Torah for Israel or on the necessity for Israelites to keep the Torah as believers in Messiah Jesus. ${ }^{14}$

Furthermore, this alternative Paul and his Gospel would not have been characterised as 'Law-free' according to this view, since (1) he stated that Gentile followers were under the 'law of Christ' (Gl 6:2; 1 Cor 9:21) and that his apostleship was for the purpose of bringing about 'the obedience of faith among all Gentiles' (Rm 1:5) and (2) as several scholars have shown, he appeared to use the Torah as the ethical framework for his Gentile churches (see earlier Davies 1980; also more recently see Bockmuehl 2003; Nanos 1996; Tomson 1990; Van Bruggen 2005).

In presenting this alternative reconstruction of Paul, I wish only to show that Sim's proposal is entirely based on a perspective of Paul that is hardly assured..$^{15}$ Sim must adjudicate his rather old-fashioned view of Paul with argumentation that takes into account all the evidence and interacts with the recent research and the new ways of reconstructing the historical Paul. In addition, his exegesis of Galatians is less than convincing and is inadequate as the basis for his discussion of Paul's and Matthew's understanding of the origin and nature of the Gentile mission.

While a more convincingly argued hypothesis of Paul is necessary, even the one suggested by recent research of a Torahobservant Paul still shows some tension with the Matthean perspective that has Sim advocated. It is to this second issue that I now turn my attention.

\section{Matthew's Mission(s) to Jews and Gentiles}

Is it really the case that, with the Great Commission, Matthew's Gospel promulgated a Torah-observant mission to the nations, as Sim has ardently affirmed? While a host of Matthean scholars would reject such an assertion outright on the basis of an extra muros view, those of us who agree with Sim's view of the Jewish Christian character of the First Gospel must, at the very least, entertain this possibility.

Additionally, Sim is to be commended for rightly having pointed out the implausibility of the prevalent interpretative approach to the Gospel that holds, on the one hand, the Jewish Christian nature of the Gospel, while, on the other, interprets Matthew 28:16 to 20 as universalising Matthew 10:5 to 6. This universalising interpretation, which assumes a single Torahfree mission to both Jew and non-Jew, according to Sim, proves ultimately 'implausible' because it 'too often ignores the Jewish dimension of the universal mission' (2008:386).

Sim has rightly argued that a universal mission that is Law-free stands in tension with the Gospel's emphasis on the Torah (Mt 5:17-19). Sim's alternative interpretation has maintained the universalising element of the prevailing interpretation but has turned it on its head by taking the single mission to be a Torahobservant one (2008:385-388). Is it true that we are left with only

\section{See Rudolph (2008:10). Also see Tomson (2001b:267-268).}

15.See, for example, the useful Wirkungsgeschichte by Bockmuehl (2006:121-136) of Peter and Paul in the earliest Christian writings and iconography, which revealed a very different history of the early church to the dialectical approach followed by Sim. 
these two alternatives: a universalised mission that is either Law-free or Law-observant?

In this section, I wish to assess the claim that Matthew advocated a Torah-observant mission to the Gentiles. I begin with Sim's characterisation of Matthew's first mission (Mt 10:5-6) as a 'Lawobservant mission'. Sim has stated that '[v]ery few scholars would dispute that the original mission to the Jews in Matthew's narrative was Law-observant' (2008:385). Sim's point seems both reasonable at first and incontrovertible, since the original mission was directed towards the 'lost sheep of the house of Israel'. On second thought, however, I am not so sure that most scholars would agree that Jesus' Galilean mission, as Matthew described it, was justifiably characterised as a 'Law-observant mission' in the way that Sim has meant, since Law observance hardly appears integral to the mission or message of Jesus and his disciples according to Matthew's story.

In the Matthean portrayal, Jesus did not send the Twelve out on mission for the purpose of enforcing Torah obedience among the disenfranchised in the Greater Galilean region. He sent them rather to proclaim the soon-coming Kingdom and to dispense the blessings of that Kingdom as they travelled from city to city (Mt 10), as he himself had done (Mt 8-9). It is true that Jesus' and the Twelve's mission was directed to the 'lost sheep of the house of Israel' (Mt 10:6; 15:24) ${ }^{16}$ and that the Matthean Jesus believed following him and preparing for the coming of the Kingdom would produce a surpassing righteousness (5:20). But how can this mission be justifiably characterised as 'Law-observant'? Of course it can, if, by this, you mean that the target audience of the original mission was Israelites. This, however, is much less than that which Sim has implied with this adjectival phrase. I have a difficult time seeing where in Matthew's narrative of the Galilean mission (Mt 4:12-19:1) one finds an emphasis on the Law-observant nature of the mission, where one finds a focus on the enforcement of Law observance.

In fact, quite to the contrary, Matthew portrayed Jesus' mission as one that, rather than enforcing scrupulous Law observance, served segments of society that were ostracised by 'Torahobservant' Pharisees. I have in mind here Jesus eating with 'tax collectors and sinners' (Mt 9:10-13). Jesus' response to the Pharisees seemed to reveal a mission that would not be best characterised as 'Law observant': 'Go and learn what this means, "I desire mercy, not sacrifice." For I have come to call not the righteous but sinners.' With this statement, Jesus did not intend to undermine the importance of the Torah for Israel but it does, nevertheless, suggest that Jesus' mission did not begin with matters of Torah observance.

It is apparent that what Sim meant by his characterisation of the mission is that Jews were expected to follow Jesus and keep the Mosaic Law. For the Galileans and Judeans of the early first century, following Jesus meant keeping the Torah, thereby remaining firmly within their covenant obligations to Yahweh. In fact, Matthew took great pains to show that Jesus upheld the Torah and that the conflicts that he had with his contemporaries over Torah observance were related to its interpretation and not to its continuing validity (Mt 5:17-48). Nevertheless, what warrant justifies this observation as evidence for the claim that Jesus had a 'Law-observant mission'? It seems that Sim has overreached the evidence in asserting that Matthew's mission to the Jews was 'Law observant'. While it is true that his Galilean and Judean followers saw no contradiction between following Jesus and keeping the Messianic Torah, to characterise Jesus' Galilean mission as a 'Law-observant mission', at least in the way that Sim has done, does not emerge naturally from Matthew's story. Matthew's point of emphasis in his presentation of Jesus' mission does not seem to be on Torah observance. The moniker, it seems to me, is therefore inappropriate.

16.For a thorough study of this logion, see Willitts (2007)
The point is: the claim that a mission to the nations is by definition a Law-observant mission because the first mission was a Law-observant mission does not convince. What Matthew no doubt affirmed was the continuity between following Jesus and Israel's historic covenant. And it is certainly true, as Sim has pointed out, that, whatever we make of the Great Commission (Mt 28:16-20), it cannot be said that discipleship for Israelites represented an abrogation of their covenantal responsibilities as the prevalent universalising approach does.

Furthermore, if it can be shown - against Sim and the consensus of Matthean scholarship - that the final mission command in Matthew was not a revision of the first, then, perhaps, the problem created by the interpretation of a single mission with a single message evaporates all together. In other words, if the target audience was ethnically distinct from Israel in the second mission, one might expect there to have been some difference in the nature of the two missions.

As it turns out, some recent but, as-yet, to be appreciated, voices have argued for this very point. These scholars have asserted that the two mission statements, when compared, reveal significant differences that likely imply two distinct missions, with distinct ethnic target groups and, consequently, distinct missional tasks. I have argued elsewhere in greater detail than is possible here that the 'universalising' or salvation-historical interpretation of the Great Commission is problematic because of its tendency to create theological abstractions foreign to Matthew's historical context (see Willitts 2007). In addition, the German scholar Von Dobbeler (2000; also see Wilk 2002:129-130) has presented a convincing alternative interpretation of the relationship between the two mission commands in Matthew. ${ }^{17}$

The essence of Von Dobbeler's argument was that the final mission command should not be seen as either replacing or expanding the first mission command (2000:24-27). Rather, they should be seen as complementary (Komplementarität), even if distinct, expressions of the one mission of Jesus, the Messiah. The Von Dobbeler interpretation began with the observation that the two mission commands revealed a distinction in target groups (Zielgruppen), goals (Ziele) and tasks (Aufträgen). Von Dobbeler then explained:

Sie stehen freilich nicht einfach nebeneinander, sondern sind aufeinander bezogen als komplementäre Wirkungen des Messias Jesus und der in seiner Nachfolgen messianisch wirkenden Jünger.

(Von Dobbeler 2000:27-28)

The aim of the mission of Jesus and his disciples was accordingly ethnically distinct: two different groups entailing two different missionary tasks. The mission to Israel involved the announcement of the coming of the kingdom of God and Israel's restoration ( $\mathrm{Mt} \mathrm{10).} \mathrm{In} \mathrm{contrast,} \mathrm{the} \mathrm{mission} \mathrm{to} \mathrm{the} \mathrm{nations} \mathrm{meant}$ the extension of the kingdom of God throughout the whole earth and implied the conversion of the nations to the living God (Mt 28). The Jewish Scriptures envisaged a time when Israel would be restored and, as a consequence, the nations as nations would turn from idolatry and worship Yahweh. Von Dobbeler understood Matthew as articulating missions that reflected this eschatological reality: 'Restitution Israels und Bekehrung der Heiden wären demnach die komplementären Aspekte der einen messianischen Sendung' (2008:28). Furthermore, he summarised as follows:

Matthäus sieht die Jünger Jesu sowohl zu den verlorenen Schafen des Hauses Israel als auch zu den Heidenvölkern gesandt, freilich mit jeweils unterschiedlich akzentuierten Aufträgen: Im Blick auf Israel geht es um die Restitution des Volkes, im Blick auf die

17.The recent essay by Konradt (2004) offered a friendly critique of Von Dobbeler's thesis but, in the end, can be seen to support the essence of Von Dobbeler's thesis but, in thedt's piece be argument. Konrad's piece is useful insofar as it revealed that Matthew's mission command to the nathew' unfolding Christology: 'Matthaus hat seine Noverzahlung der Jesusgeschicht durch ein christologisches Erzählkonzept strukturiert, das die Betonung der heilsgeschichtlich begründeten Sonderstellung Israels und die Universalität des Heils in Christus miteinander vermittelt' (2004:399-400). 
Heidenwelt um die Bekehrung zu dem lebendigen Gott. Beiden Sendungen konvergieren darin, daß sie in komplementärer Weise Ausdruck der einen messicanischen Sendung in Israel als auch für die Heidenmission von zentraler Relevanz ist.

(Von Dobbeler 2000:41)

The perspective of a complementary relationship between the two mission commands more or less outflanks Sim's arguments for a Law-observant mission by rendering it unnecessary. With a complementary approach, we are able to maintain the thoroughly Jewish perspective and its apparent emphasis on the continuing validity of Torah observance for Jewish believers in Jesus, while, at the same time, reflect the equally Jewish perspective that the nations as nations will worship Yahweh as a result of Israel's restoration. This approach allows Matthew's Gospel to offer a bifurcated and complementary mission to both Jews and nonJews that is consistent with messianic perspectives in the Jewish Scriptures and in some segments of Second Temple Judaism. ${ }^{18}$

One final factor informing Sim's understanding of the Torahobservant nature of the Gentile mission is his belief that Jesus' command to 'make disciples of all nations ... teaching them to

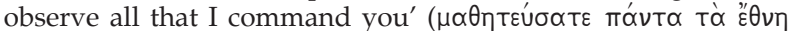

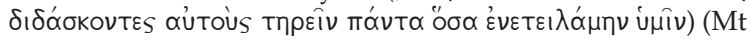
28:19-20) implies Jesus teaching about the Torah in Matthew 5:17 to 19 . He has reasoned as follows:

These three sayings must be taken literally and seriously. When we do so, it becomes almost inconceivable that the risen Jesus at the end of the Gospel simply dismissed the necessity for circumcision (or any other ritual requirement of the Torah) and replaced it with baptism. If Matthew was consistent on the fundamental subject of the Torah, then we have to conclude that the universal mission enjoined by the risen Lord, which was to be conducted prior to the parousia, must have proclaimed a Law-observant gospel. Circumcision as well as baptism must have been required of Gentile converts.

$(\text { Sim 2008:386-387) })^{19}$

I would like to assess Sim's interpretation by examining one of the encounters that Jesus had with a Gentile in Matthew, the Canaanite woman in Matthew 15. It seems reasonable to consider Jesus' encounters with Gentiles in the Gospel as a way forward in hypothesising what the commands might have entailed. And our findings from this approach can be compared with Sim's assertions. To put it simply, did the Matthean Jesus require of Gentiles what he required of Israel?

A careful reading of Matthew 15:21 to 28 reveals several relevant points in this regard. Firstly, the moniker 'Canaanite' is not merely a matter of Matthew 'archaising' in order to evoke images of Israel's enemies. ${ }^{20}$ More likely, Matthew could be said to be scripturalising ${ }^{21}$ the woman's identity to reveal concern for the status of non-Israelite subjects within the restored kingdom of Israel. ${ }^{22}$

18.This interpretation provides a more convincing explanation than Davies himself gave for his observation: "There can be no question that ... "universalistic" no less than "particularistic" sayings are congenial to Matthew; the former no less than the latter were an expression of his interests' (1964:330).

19.The appeal by $\operatorname{Sim}(2008: 387)$ to Qumran as a parallel to Matthew for a contemporary Jewish sectarian group remaining silent about circumcision, contemporary Jewish sectarian group remaining silent about circumcision, athough obviously implying its validity, came across as special pleading. That no Gentiles were members of the community or that the Qumranites had any interest in a Gentile mission make any comparison on this issue unconvincing.

20.See Boring (1995:336), Davies and Allison (1991:547), Grundmann (1968:376), Keener (1999:414), Meier (1980:172), Nolland (2005:631-632) and Senior (1998:181).

21.This is a term that I created to distinguish my view from those who use archaising. While the function of the two terms is the same, in other words a familiar scriptural term to designate the identity of the woman, I wanted to avoid the word 'archising' because it is so closely linked with the idea that 'Canaanite' evokes images of Israel's enemies. Also see Davies (1993:115).

22.See Levine's perceptive comment, although she clearly arrived at different conclusions evinced by the following: 'By labeling the woman a Canaanite, Matthew refuses to dismiss the non-Jewish population of the land' (2001:40) Also, Kick (1994:110-111) recently argued that Matthew's term 'Canaanite' should be understood as a reminder to his readers of YAHWEH's land promise
Secondly, in view of Matthew's belief in the soon-coming (and present) kingdom of God/Israel, the exchange between Jesus and the Canaanite woman likely provided confirmation to a Jewish reader of Jesus' Messianic identity. The Canaanite woman was portrayed as submitting to Jesus' authority as the Davidic Son in an area where the rule of David once reached. While the leadership of Israel rejected Jesus' identity and authority, the Canaanite woman acknowledged and appealed to it.

Thirdly, Matthew's portrayal of the Gentile woman was one in which the woman exhibited 'an exemplary Jewish faith' in that she recognised 'the saving intervention of the God of Israel through his messiah'. ${ }^{23}$ Indeed, on the basis of this faith ( $\mu \varepsilon \gamma \alpha \dot{\alpha} \lambda \eta$ бou $\eta$ mí(IS), Jesus granted her request (Mt 15:28). ${ }^{24}$ In other words, as Kick (1994) has persuasively argued, the Gentile woman 'stands near' (nahesteht) the Jewish eschatological outlook of Matthew's Jesus; the woman shared the same perspective and saw her salvation as tied up with Jesus' successful completion of his vocation to shepherd Israel.

Evidence of her Jewish faith is seen in two ways..$^{25}$ Firstly, her approach and address before Jesus were appropriate to his identity as God's Messiah: she prostrated herself (15:25), acknowledged him to be Israel's legitimate king (15:22) and recognised his lordship (note the use of 'Lord' three times in the context: 15:22, 25 and 27). In addition, with the accompanying parable about the children and dogs $(15: 24,26)$, she acknowledged her nationality and willingly submitted herself to Israel's Messianic Shepherd-King. ${ }^{26}$ Her response to Jesus' rebuttal revealed that, although acknowledging the centrality of Israel, she asserted that she was included at Israel's table, albeit as one of Israel's 'puppies' (kuvópı $\alpha$ ).

Her agreement with Jesus' parable, however, was to a different effect $(15: 26)$. She showed that she understood herself to be a part of the 'house of Israel',27 admittedly not as one of the

lost sheep, but she asserted that she was nonetheless allowed access to the breadcrumbs from the master's table..$^{28}$ Applying the very parable that Jesus used, the woman asserted that she could participate as a Gentile within the 'house of Israel'. Just as a puppy participates in the household of a family around the master's table, receiving what is appropriate to it, so the woman participated as a Gentile within the house (or kingdom) of Israel, receiving the share of the Messianic Kingdom appropriate to her. In this way, Hill (1972) was probably right to have suggested that

(footnote 22continues..)

to Israel, seen in texts like Deuteronomy 11:12 and Leviticus 25:23

23.Both quotations are from Nolland (2005:632). Some commentators, like Love (2002:17-18), had difficulty accepting that a Gentile woman would have understood the significance of the terms 'Lord' and 'Son of David'. Hence, they suggested that she understood them in a way other than free from the Jewish Messianic meaning. The fact of the matter is that whether or not the woman in actuality understood the Messianic significance of the terms is unknowable and irrelevant. Clearly, Matthew exploited their full Messianic implications.

24.Also see Patte (1987:222).

25.Jackson (2002) made the case that this story represented a conversion to Judaism; in effect, the woman had become a proselyte. She writes that 'the Judaism, in effect, the (2000.946). For a con (t) see Jackson (2000:945-946). Yet Nolland's critique is legitimate: 'despite her very Jewish faith, the Canaanite woman becomes a beneficiary of Jesus' ministry not as a freshly made Jewess, but as a Gentile' (2005:636; n217; also see Nolland [2004]). Nanos (2009a [forthcoming]) has an interesting alternative interpretation of the woman's mixed identity being both Israelite and Gentile and the term 'Gentile', in his view, is therefore not perhaps best.

26. Nolland (2005:635) was right to translate the opening words of Matthew 15:27

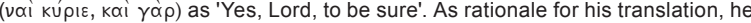
states that 'following a linking koí ('and'), it introduces what is to be seen as an implication drawn out from what has been affirmed.

27.See Nortjé-Meyer (2000:71), who commented similarly, although she reached quite a different conclusion.

28. Also see Mello (1999:287-288), Radermakers (1972:211) and Wilk (2002:146). Contra Sim (1998:224), also see Davies and Allison (1991:556), who thought that Jesus finally simply gave in to the woman. 
'crumbs' did not imply that the woman received only a fragment of what was given to Israel. The point, according to Hill, was that 'their needs are adequately met'. ${ }^{29}$

What was insightfully recognised by Kick (1994) is that he affirmed the points of view of both main characters. ${ }^{30}$ Matthew's story placed the vocation (die Aufgabe) of Jesus for 'the lost sheep of the house of Israel' alongside the Canaanite's request for the life of the Messianic age. The latter was not superseded or abrogated by the former but was the very basis on which the latter was made possible. Together, they were the complete picture of the coming of the kingdom of God according to Matthew. ${ }^{31}$

Matthew told a Jewish story about Israel's Davidic Messiah, Jesus, in which he extended mercy to a non-Jewish subject, granting her request. His action was, perhaps to the surprise of some, the result of the woman's resolute act and proper political Israel-centric outlook. ${ }^{32}$ She acknowledged her subordinate national identity vis-à-vis Israel and addressed Jesus in those terms without once doubting her right to a share in the powers of the Messianic age. ${ }^{33}$ The narrative, then, revealed that Gentiles had a right to exist and participate in the Messianic age by adopting the appropriate posture towards Israel's Messiah Bacon (1930) concluded something similar about this episode nearly a century ago:

To Matthew the Canaanite woman is as typical an example of the stranger adopted among the people of God as Rahab the Canaanite harlot and Ruth the Moabitess, whom he specially mentions in his genealogy of Christ. Along with the believing Centurion, she is to Matthew the type of many who are to come from the East and from the West to "sit down with Abraham Isaac and Jacob" at the messianic feast.

(Bacon 1930:227)

In view of this story and others like it in the Gospel (e.g. Magi [2:1-12], Centurion [8:5-13]), it is difficult to be convinced of a view that Matthew's outlook on Gentiles and their entrance into the kingdom of Heaven presupposed proselytisation. ${ }^{34}$ Instead, it seems more likely that making disciples of all nations involved instructing them in the Lord's teaching that specifically applied to them. This more nuanced approach to Gentiles and their eschatological fate would be at home in the variegated perspectives of first-century Judaism about the destiny of Gentiles. ${ }^{35}$ One such view was that of the so-called 'righteous Gentiles', who had a place in the age to come by keeping the Torah that applied to them. ${ }^{36}$ While I am not arguing that this was what Matthew presupposed, I think that it is at least as much, if not more likely, an interpretation than Sim's, given the evidence in Matthew. However, caution on this question is the most proper posture and it should not, in the end, be made a foundation of any reconstruction of Matthew's understanding of the Gentile mission because, as Bockmuehl rightly observed, 'although Matthew clearly tries to formulate a "Jesus halakhah" (e.g. in 5.21-48; 19:3-9), many questions remain wrapped in diplomatic silence' (2003:163).

\section{Hill (1972:254)}

30.Kick (1994:113).

31. Far from a replacement of Israel by an abstract idea of 'faith', Kick (1994:114) rightly thought that this Matthean text described the coexistence (ein Miteinander) of Jewish faith and Gentile Christian faith on the foundation of Israel's faithfulness to YAHWEH and YAHWEH's promise of faithfulness to Israel.

32.See Levine (2001:36)

33.Also see Wilk (2002:146).

34.Contra Jackson, see note 23 above.

35.Sim has shown his awareness of the variety of views held by first-century Israelites concerning Gentiles' relationship to the Torah. See Sim (1996b:174177; 1998:17-19).

36. For a discussion of the various positions held by first-century Israelites concerning Gentiles, see Bockmuehl (2003), Donaldson (1997:51-78), Nanos (1996), Tomson (1990) and Wyschogrod (2004).

\section{The Comparison of Matthew and Paul}

One final point that I would like to raise concerning Sim's argument for an anti-Pauline Matthew relates to his comparative methodology. Sim has chided Matthean scholars for not seriously considering the question of Matthew's view of Paul (2002:768). However, in light of recent research, it is perhaps more legitimate to question a modern interpreter's ability to offer anything by way of a convincing answer to just such a question. Several factors, which are more seriously appreciated in contemporary scholarship than in the past, conspire against claims that are based on a comparison of Matthean and Pauline literature.

In the early 1980s, Mohrlang published a comparative study of Matthew's and Paul's ethics, concluding the entire discussion with a section titled the 'Factors underlying their differences' (1984:128-132). There he outlined seven factors that he believed went a long way to explaining the differences between the two figures on the question of ethics. ${ }^{37}$ What Mohrlang seemed not to appreciate at the time was that the factors that he listed did not simply make Matthew and Paul different but also actually revealed the near impossibility of coming to anything resembling a convincing claim based on a literary comparison of the two. It would be one thing if Matthew and Paul shared a common social context - which they did not - if they dealt with similar rhetorical concerns - which they did not - or if they wrote in a similar genre - which they did not. Because Matthew and Paul shared none of these, claims of stark theological difference and, certainly, claims of explicit refutation are highly speculative and therefore unconvincing.

Let us take the issue of genre as an example. Mohrlang admitted that the issue of genre 'provides perhaps the single greatest difficulty for any attempt to compare the two writers' thought comprehensively' (1984:130). Since Mohrlang's observation, significant progress in the area of genre criticism has only strengthened his assertion. Led by the work of Burridge (1992; 2004), ${ }^{38}$ genre criticism has not only largely settled the issue of the Gospel's genre but also clarified the interpretative limits within a genre. If the gospels are Greco-Roman Bíol, their concern is singularly Jesus of Nazareth. Given the focus of the Gospel's genre, however, it becomes much more difficult to use the Gospel as a window into concerns of the Matthean community. This does not, of course, mean that we cannot know anything about the author and his community's historical context from the concerns observable from the Gospel but it does mean that anything more than a description of their general contours is going to be less convincing.

On the other hand, given the severely situational nature of Paul's letters, very little can be known about Paul's views beyond the rhetorical context of his pastoral concern for his Gentilebelieving communities. ${ }^{39}$ No longer is it therefore justifiable to universalise Paul's statements, especially about the Torah, beyond their Gentile horizon. Paul clearly believed that Gentiles should not be circumcised and take on the yoke of the Torah but it is very likely that this would not have been his view for Israel in light of his 'rule' stated in 1 Corinthians 7:17 to 24:

However that may be, let each of you lead the life that the Lord has assigned, to which God called you. This is my rule in all the

37.Mohrlang's list consisted of the following seven factors: (1) social factor (2) polemical factor; (3) motivational factor; (4) psychological factor; (5) Christological factor; (6) literary factor; and (7) interpretative factor (1984:128131). While several of these are open to critique, factors 1,2 and 6 are clearly unassailably fundamental.

38. In an autobiographically orientated reflection, Burridge remarked that 'It is now clear that this approach has won widespread acceptance and that most scholars on both sides of the Atlantic and across the disciplines accept that the gospels on both sides of the Atlantic and across the disciplines accept that the gospels are in a form of ancient biography'. Therefore, 'our arguments for biologica genre of the gospels have rapidly become part of a new consensus' (2004:269;
306).

39.Burridge (2004:248-249) pointed at the significance of the distinction between the genres of Gospel and Paul's letters but does not develop this. 
churches. Was anyone at the time of his call already circumcised? Let him not seek to remove the marks of circumcision. Was anyone at the time of his call uncircumcised? Let him not seek circumcision. Circumcision is nothing, and uncircumcision is nothing; but obeying the commandments of God is everything. Let each of you remain in the condition in which you were called. Were you a slave when called? Do not be concerned about it. Even if you can gain your freedom, make use of your present condition now more than ever. For whoever was called in the Lord as a slave is a freed person belonging to the Lord, just as whoever was free when called is a slave of Christ. You were bought with a price; do not become slaves of human masters. In whatever condition you were called, brothers and sisters, there remain with God..$^{40}$

Recently, Rudolph has usefully commented as follows: 'Paul's statement . . . required Jesus-believing Jews to continue to live the circumcised life as a matter of calling and not to assimilate into a Gentile lifestyle' (Rudolph 2008:10; also see Tomson 2001b:267-268).

Therefore, the issues of social context, rhetorical concerns and genre present significant methodological obstacles that may very well undermine the kind of comparison that Sim has undertaken. While it is possible to describe Matthew and Paul's outlook on questions that arise out of their literary creations, it is altogether another thing to use these as definitive statements on shared topics that can then be legitimately compared with the other.

\section{CONCLUSION}

In light of the foregoing discussion, I cannot agree with Sim that the Great Commission in Matthew 28:19 to 20 promulgated a Torah-observant mission to the Gentiles or, more fundamentally, that Matthew implicitly and explicitly refuted Paul. I can understand how Sim came to this conclusion - his argumentation is coherent, well argued and supported with evidence - but I think that neither the Gospel's plain sense nor Paul's own statements about the Gentile mission and apostolic career lead a reader to this conclusion.

To me, Sim has marshalled evidence from the First Gospel that did not directly or immediately refer to Paul or his mission. And only after one accepts Sim's assumption that Matthew's outlook was anti-Pauline does the evidence connect to the claim. ${ }^{41}$

But this is question begging... because nowhere did Matthew specifically mention Paul. Furthermore, the so-called allusions to Paul pointed out by Sim were, at best, veiled and subjective with little to anchor such claims in the narrative of Matthew. Too often has Sim appealed to evidence either that cannot be substantiated with a high degree of certainty or whose warrant - assumptions that connect the evidence with the claim - are highly speculative. Furthermore, Sim's baurite reconstruction of early Christian history, within which his hypothesis has convincing power only, requires a certain kind of historical Paul that is becoming a less convincing historical portrait of the Apostle to the Gentiles

Sim's proposal then appears to me to be severely overstated and, at crucial points, to be overreaching the evidence that he has cited both in Matthean and Pauline literature. Therefore, Stanton's assessment seems to be the most convincing statement on the relationship between Matthew and Paul. However, while the early position of Davies (1964) is in need of revision, as Sim himself has pointed out (2002:771), Davies's central point must also remain a live option. To put it plainly, it is possible

40.This Scripture quotation was taken from the NRSV.

41. Perhaps telling in this regard is his soon-to-be published essay in the Journal for New Testament Studies, where he has overtly stated in his abstract that 'An intertextual relationship between the Gospel and the Pauline corpus becomes clear once we understand that Matthew, as a Law-observant Christian Jew, was opposed to the more liberal theology of Paul' (2009). that, if Matthew and Paul had been contemporaries - contrary to both Luz and Sim - they could have struck up a splendid friendship. ${ }^{42}$

\section{REFERENCES}

Bacon, B.W., 1930, Studies in Matthew, Constable, London.

Bauckham, R., 1990, Jude and the relatives of Jesus in the early church, T \& T Clark, Edinburgh.

Bauckham, R., 1995, 'James and the Jerusalem church', in R. Bauckham (ed.), The book of Acts in its Palestinian setting, 4, pp. 415-480, Eerdmans, Grand Rapids.

Bauckham, R., 2006, 'James and the Jerusalem community', in O. Skarsaune \& R. Hvalvik (eds.), A history of Jewish believers in Jesus: The first five centuries, pp. 55-95, Hendrickson, Peabody.

Bockmuehl, M., 2003, Jewish law in gentile churches: Halakhah and the beginning of Christian public ethics, Baker, Grand Rapids.

Bockmuehl, M., 2006, Seeing the Word: Refocusing New Testament study, Baker, Grand Rapids.

Boring, M.E., 1995, 'Matthew', in L.E. Keck (ed.), New Interpreter's Bible, vol. 8, pp. 89-505, Abingdon Press, Nashville.

Brandon, S.G.F., 1957, The fall of Jerusalem and the Christian church: A study of the effects of the Jewish overthrow of AD 70 on Christianity, SPCK, London.

Burridge, R.A., 1992, What are the Gospels? A comparison with Graeco-Roman biography, Cambridge University Press, Cambridge.

Burridge, R.A., 2004, What are the Gospels? A comparison with Graeco-Roman biography, Eerdmans, Grand Rapids.

Campbell, W.S., 2006, Paul and the creation of Christian identity, T \& T Clark, London.

Catchpole, D., 2002, Resurrection people: Studies in the resurrection narratives of the Gospels, Smyth \& Helwys, Macon.

Davies, M., 1993, Matthew. Readings: A new biblical commentary, JSOT Press, Sheffield.

Davies, W.D., 1964, The setting of the sermon on the mount, Cambridge University Press, Cambridge.

Davies, W.D., 1980, Paul and rabbinic Judaism: Some rabbinic elements in Pauline theology, Fortress Press, Minneapolis.

Davies, W.D. \& Dale, C.A., 1991, The Gospel according to Saint Matthew, T \& T Clark, Edinburgh.

Donaldson, T.L., 1997, Paul and the Gentiles: Remapping the apostle's convictional world, Fortress Press, Minneapolis.

Ehrensperger, K., 2007, Paul and the dynamics of power: Communication and interaction in the early Christ-movement, $\mathrm{T}$ \& T Clark, London.

Eisenbaum, P., 2000-2001, 'Is Paul the father of misogyny and antisemitism?' Cross Currents 50(4), 506-524.

Gager, J.G., 2000, Reinventing Paul, Oxford University Press, Oxford.

Grundmann, W., 1968, Das Evangelium nach Matthäus, Evangelische Verlagsanstalt, Berlin.

Harrington, D.J., 2008, 'Matthew and Paul', in D.C. Sim \& B. Repschinki (eds.), Matthew and his Christian contemporaries, pp. 11-26, T \& T Clark, London.

Hill, D., 1972, The Gospel of Matthew, Oliphants, London.

Hvalvik, R., 2006, 'Named Jewish believers connected with the Pauline mission', in O. Skarsaune \& R. Hvalvik (eds.), A history of Jewish believers in Jesus: The first five centuries, pp. 154-178, Hendrickson, Peabody.

Jackson, G.S., 2000, 'Are the "nations" present in Matthew?', HTS Teologiese/Theological Studies 56(4), 935-948.

Jackson, G.S., 2002, "Have mercy on me": The story of the Canaanite woman in Matthew 15:21-28', Sheffield Academic Press, London.

Jewett, R., 2007, Romans: A commentary, Fortress Press, Hermeneia.

Keener, C.S., 1999, A commentary on the Gospel of Matthew, Eerdmans, Grand Rapids.

42. What I mean by 'friendship' here is best defined by the profound reflections of Lewis in Four loves (1960). 
Kick, M., 1994, 'Ich bin gesandt nur zu den verloren Schafen des Hause Israel: Matthäus 15, 24', in S. Wagner, G. Nützel \& M. Kick (Hrsg.), (Anti-)Rassistische Irritationen: Biblische Texte und interkulturelle Zusammenarbeit, pp. 109-114, AlektorVerlag, Berlin.

Konradt, M., 2004, 'Die Sendung zu Israel und zu den Völkern im Matthäusevangelium im Lichte seiner narrativen Christologie', Zeitschrift für Theologie und Kirche 101, 397425.

Levine, A.J., 2001, 'Matthew's advice to a divided readership', in D.E. Aune (ed.), The Gospel of Matthew in current study: Studies in memory of William G. Thompson, pp. 22-41, Eerdmans, Grand Rapids.

Lewis, C.S., 1960, The four loves, Harvest Books, New York.

Love, S.L., 2002, 'Jesus, healer of the Canaanite woman's daughter in Matthew's Gospel: A social-scientific inquiry', Biblical Theology Bulletin 32, 11-20.

Lüdemann, G., 1989, Opposition to Paul in Jewish Christianity, Fortress Press, Minneapolis.

Luz, U., 1995, The theology of the Gospel of Matthew, transl. J. Bradford Robinson, ed. by J.D.G. Dunn, New Testament Theology Series, Cambridge University Press, Cambridge.

Marcus, J., 2000, 'Mark: Interpreter of Paul', New Testament Studies 46, 473-487.

Martyn, J.L., 1997a, in W.F. Albright \& D.N. Freedman (eds.) Galatians, Doubleday, New York.

Martyn, J.L., 1997b, Theological issues in the letters of Paul. Studies of the New Testament and its world, T \& T Clark, Edinburgh.

McRay, J., 2003, Paul: His life and teaching, Baker Academic, Grand Rapids.

Meier, J.P., 1980, Matthew, Veritas Publications, Dublin.

Mello, A., 1999, Évanglile Selon Saint Matthieu, transl. A. Chevillon, Lectio Divina, Les Éditions du Cerf, Paris.

Mohrlang, R., 1984, Matthew and Paul: A comparison of ethical perspectives, Cambridge University Press, Cambridge.

Nanos, M.D., 1996, The mystery of Romans: The Jewish context of Paul's letter, Fortress Press, Minneapolis.

Nanos, M.D., 2002, 'What was at stake in Peter's "Eating with Gentiles" at Antioch?', in M.D. Nanos (ed.), The Galatians debate: Contemporary issues in rhetorical and historical interpretation, pp. 282-318, Hendrickson, Peabody.

Nanos, M.D., 2009a (forthcoming), 'Paul's reversal of Jews calling Gentiles "dogs" (Philippians 3:2): 1600 years of an ideological tale wagging an exegetical dog?' Biblical Interpretation

Nanos, M.D., 2009b (forthcoming), 'Rethinking the "Paul and Judaism" paradigm: Why not "Paul's Judaism"?', in M.D. Given (ed.), Paul unbound: Other perspectives on the apostle, Hendrickson, Peabody.

Nolland, J., 2004, 'A review of "Have mercy on me". The story of the Canaanite woman in Matthew 15:21-28', Journal of Theological Studies, 55, 234-235.

Nolland, J., 2005, The Gospel of Matthew, Eerdmans, Grand Rapids.

Nortjé-Meyer, L., 2000, 'Gentile female characters in Matthew's story: An illustration of righteousness', in I.R. Kitzberger (ed.), Transformative encounters: Jesus and women re-viewed, pp. 54-76, Brill, Leiden

Patte, D., 1987, The Gospel according to Matthew: A structural commentary on Matthew's faith, Fortress Press, Philadelphia.

Radermakers, J.S.J., 1972, Au fil de l'évangile: Selon saint Matthieu: 2. Lecture continue, Institut d'Etudes Theoloiques, HeverleeLouvain.

Rudolph, D., 2006, A Jew to the Jews: Jewish contours of Pauline flexibility in 1 Corinthians 9:19-23, PhD thesis, University of Cambridge.
Rudolph, D., 2008, 'Paul's "Rule in all the churches" (1 Cor 7:1724) and Torah-defined ecclesiological variegation', paper presented at American Academy of Religion, Chicago, 3 November.

Rudolph, D., 2009 (forthcoming), A Jew to the Jews: Jewish contours of Pauline flexibility in 1 Corinthians 9:19-23, Mohr-Siebeck, Tubingen.

Senior, D., 1998, Matthew, Abingdon Press, Nashville.

Sim, D.C., 1995, 'The Gospel of Matthew and the Gentiles', Journal for the Study of the New Testament 57, 19-48.

Sim, D.C., 1996a, Apocalyptic eschatology in the Gospel of Matthew, Cambridge University Press, Cambridge.

Sim, D.C., 1996b, 'Christianity and ethnicity in the Gospel of Matthew', in M.G. Brett (ed.), Ethnicity and the Bible, pp. 171195, Brill, Leiden.

Sim, D.C., 1998, The Gospel of Matthew and Christian Judaism: The history and social setting of the Matthean community, T \& T Clark, Edinburgh.

Sim, D.C., 2002, 'Matthew's anti-Paulinism: A neglected feature of Matthean studies', HTS Teologiese Studies/Theological Studies 58(2), 767-783.

Sim, D.C., 2007, 'Matthew 7:21-23: Further evidence of its antiPauline perspective', HTS Teologiese Studies/Theological Studies 53, 325-343

Sim, D.C., 2008, 'Matthew, Paul and the origin and nature of the Gentile mission: The Great Commission in Matthew 28:16-20 as an anti-Pauline tradition', HTS Teologiese Studies/ Theological Studies 64(1), 377-392.

Sim, D.C., 2009 (forthcoming), 'Matthew and the Pauline corpus: A preliminary intertextual study', Journal for the Study of the New Testament.

Sim, D.C. \& Boris, R., 2008, Matthew and his Christian contemporaries, T \& T Clark, London.

Stanton, G., 1993, A Gospel for a new people: Studies in Matthew, Westminster/John Knox Press, Louisville.

Tomson, P.J., 1990, Paul and the Jewish law: Halakha in the letters of the apostle to the Gentiles, Fortress Press, Minneapolis.

Tomson, P.J., 2001a, "If this be from heaven . ..": Jesus and the New Testament authors in their relationship to Judaism, Sheffield Academic Press, Sheffield.

Tomson, P.J., 2001b, 'Paul's Jewish background in view of his law teaching in 1 Cor 7', in J.D.G. Dunn (ed.), Paul and the mosaic law, pp. 251-270, Eerdmans, Grand Rapids.

Van Bruggen, J., 2005, Paul: Pioneer for Israel's Messiah, transl E.M. van der Maas, P \& R Pub, Phillipsburg.

Von Dobbeler, A., 2000, 'Die Restitution Israels und die Bekehrung der Heiden. Das Verhältnis von Mt 10:5b-6 und Mt 28:18-20 unter dem Aspekt der Komplentarität. Erwägungen zum Standort des Matthäusevangeliums', Zeitschrift für die Neutestamentliche Wissenschaft 91, 18-44.

Wilk, F., 2002, Jesus und die Völker in der Sicht der Synoptiker, De Gruyter, Berlin

Willitts, J., 2007, Matthew's messianic Shepherd-King: In search of the lost sheep of the House of Israel, Walter de Gruyter, New York.

Wyschogrod, M., 2004, in R.K. Soulen (ed.), Abraham's promise: Judaism and Jewish-Christian Relations, Eerdmans, Grand Rapids.

Zetterholm, M., 2007, 'Paul and the missing Messiah', in M. Zetterholm (ed.), The Messiah: In early Judaism and Christianity, pp. 33-55, Fortress Press, Minneapolis. 